\title{
Influence of compost amendments on the hydraulic functioning of
}

\section{brownfield soils}

"This is the peer reviewed version of the following article: $A$. Whelan, C. Kechavarzi, F. Coulon, R. Sakrabani, R. Lord, Influence of compost amendments on the hydraulic functioning of brownfield soils, Soil Use and Management, Volume 29, Issue 2, pages 260-270, June 2013, which has been published in final form at DOI: 10.1111/sum.12028. This article may be used for non-commercial purposes in accordance with Wiley Terms and Conditions for Self-Archiving."

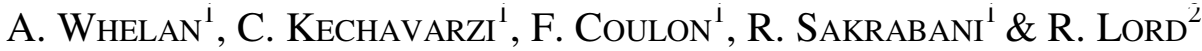

${ }^{1}$ Department of Environmental Science and Technology, School of Applied Sciences,

Cranfield University, MK43 OAL, Cranfield, UK, and ${ }^{2}$ Department of Civil and

Environmental Engineering, Faculty of Engineering, University of Strathclyde, G4 ONG,

Glasgow, UK

Correspondance: C. Kechavarzi. E-mail: Cedric.Kechavarzi@gmail.com

Running title: Hydraulic properties of compost amended soils 


\begin{abstract}
This study assessed the impact of compost on the hydraulic properties of three soils (sandy loam, clay loam and diesel contaminated sandy loam) with relatively poor physical quality typical of brownfield sites. Soils were amended with two composts at $750 \mathrm{t} / \mathrm{ha}$. Samples were also collected from a clay capped brownfield site, previously amended with 250,500 or 750t/ha of compost. Water release characteristics and saturated hydraulic conductivity were determined for all soils and physical quality indicators derived. Unsaturated flow in field profiles after compost application with two depths of incorporation and two indigenous subsoils was simulated using Hydrus-1D. Compost generally increased water retention. Hydraulic conductivity tended to decrease following compost application in sandy loam but increased in clay and clay loam, where compost addition resulted in a larger dominant pore size. Although compost improved physical quality indicators, they remained sub-optimum in clay and clay loam soil, which exhibited poor aeration, and in the contaminated sandy loam, where available water capacity was limited, possibly due to changes in wettability. Increasing application rates in the field enhanced water retention at low potentials and hydraulic conductivity near saturation but did not alter physical quality indicators. Numerical simulation indicated that the $500 \mathrm{t} / \mathrm{ha}$ application resulted in the best soil moisture regime. Increasing the depth of incorporation in the clay cap improved drainage and reduced waterlogging but incorporation in more permeable subsoil resulted in prolonged dry conditions to greater depths.
\end{abstract}

Keywords: Compost, water release characteristics, hydraulic function, brownfield, land reclamation 


\section{Introduction}

Large stockpiles of compost are being produced due to European Union regulations to reduce the amount of degradable waste sent to landfill (Antizar-Ladislao et al, 2005). Consequently, opportunities to utilise compost to return brownfield land to productive use have received increasing attention. Compost can facilitate remediation (Semple et al, 2001), whilst improving the physical (Wanas and Omran, 2006), chemical (Said-Pullicino et al, 2010) and biological properties of degraded soils (Gandolfi et al, 2010). With increasing pressure on conventional land and since renewable energy targets advocate an expansion in energy crop production (Charles et al, 2007), one potential use for neglected land is biomass crop cultivation. Throughout the UK there have been several trials to establish biomass crops on degraded land (Riddell-Black, 2002), some of them using composts (Lord and Green, 2011) and often focussing on crop response to heavy metal contamination.

Soil productivity and contaminant fate and transport are related to the ability of the soil to infiltrate, transmit and store water. To sustain yields of bioenergy crops on degraded soils, whilst managing contamination risk, an understanding of the influence of organic amendments, like compost on soil physical and hydraulic properties is needed. Compost affects soil bulk density, water retention and hydraulic conductivity (Aggelides and Londra, 2000) through the modification of porosity. Consequently, infiltration, storage and drainage of water, gas exchange, solute and contaminant movement and ease of root penetration will also be affected (Reynolds et al, 2009). Organic contaminants, such as petroleum hydrocarbons also alter soil hydraulic characteristics through changes in interfacial and surface properties (Kechavarzi et al., 2005) resulting in reduced water retention and transmission (Hyun et al., 2008). Hence, although compost may have beneficial impacts on soil physical properties, the degree to which these improvements affect soil hydraulic properties requires further consideration. Finally, compost incorporation at the soil surface 
will result in layered soil profiles whose hydraulic functioning is dependent on both the properties of the compost amended layer and the native soil but also incorporation depth and boundary conditions. Therefore, to develop appropriate compost application strategies, an understanding of the hydraulic functioning of the entire soil profile is needed.

The aim of this study was to assess, experimentally, the impact of compost on the hydraulic properties and physical quality of degraded soils. Additionally, numerical simulations were used to characterise the influence of these properties on the hydraulic functioning of a compost amended brownfield soil profile.

\section{Materials and methods}

\section{Laboratory and field samples}

The soils used to prepare homogenised laboratory samples consisted of a sandy loam and a clay loam sampled from Cranfield University farm. The soils were dried and sieved to $2 \mathrm{~mm}$. Part of the sandy loam was spiked with $12.5 \mathrm{~g} / \mathrm{kg}$ diesel fuel and aged for approximately 30 months. The soils were mixed with two composts; one composed primarily of green waste ( $31 \% \mathrm{OM})$ and one composed of approximately half green waste and half catering meat waste (52\% OM), hereafter referred to as green and meat composts respectively, at a rate equivalent to a field application of $750 \mathrm{t} / \mathrm{ha}$ assuming a $30 \mathrm{~cm}$ incorporation depth $(45$ and $62 \%$ compost by weight for the green and meat composts, respectively). The treatments were packed into cores, $6 \mathrm{~cm}$ in diameter and $5.4 \mathrm{~cm}$ deep $\left(152 \mathrm{~cm}^{3}\right)$ and replicated 3 times to a similar mass and bulk density, ranging from $0.4 \mathrm{~g} / \mathrm{cm}^{3}\left( \pm 0.02 \mathrm{~g} / \mathrm{cm}^{3}\right)$ in the pure meat compost to $1.23 \mathrm{~g} / \mathrm{cm}^{3}$ in the clay loam $\left( \pm 0.02 \mathrm{~g} / \mathrm{cm}^{3}\right)$ with a maximum variation of $7 \%$ between replicates. The compost densities $\left(0.4\right.$ and $0.6 \mathrm{~g} / \mathrm{cm}^{3}$ for the green and meat composts, respectively) were similar to those of organic soils containing a large proportion of organic matter (Kechavarzi et al., 2010). 
Field cores were also sampled from a compost-amended brownfield site. The site was a former sewage treatment works capped with clay to a depth of $0.8 \mathrm{~m}$ in Tyne and Wear, North East England. The site was amended with PAS100 compost in 2007 at three rates (250, 500 and $750 \mathrm{t} / \mathrm{ha}$ ) and planted with four energy crops to assess the feasibility of using brownfield land for energy crop production (Lord et al., 2011). Three undisturbed cores were sampled at the surface $(0-15 \mathrm{~cm}$ depth) for each application rate and at $15-30 \mathrm{~cm}$ depth in the underlying clay cap. Small metal cores $(5 \mathrm{~cm}$ deep and $5.3 \mathrm{~cm}$ in diameter) were then used to sub-sample the top of the field cores for analysis.

Soil profile descriptions, to a depth of $0.5 \mathrm{~m}$ on a $1 \mathrm{~m}$ transect, were carried out under the three compost application rates. As the site was not representative of a conventional agricultural field, traditional soil profile descriptions were not possible and so focused on the depth of the compost layers, the presence of roots, stones and other materials and other distinctive features.

\section{Hydraulic functions and soil physical quality parameters}

Water release characteristics were measured using sand table apparatus at water potentials, expressed in water height equivalents, of $0,30,50$ and $100 \mathrm{~cm}$ and pressure cell apparatus at pressure heads of 200, 500, 1000, 1500, 2000, 5000, 10000 and $15000 \mathrm{~cm}$. The Van Genuchten (1980) equation was fitted to the water release curve data using the RETC code (Van Genuchten et al, 1991):

$\theta=\left(\theta_{\text {sat }}-\theta_{\text {res }}\right)\left[1+\left(\frac{1}{\propto h}\right)^{n}\right]^{-m}+\theta_{\text {res }}$

Where $\theta$ is the moisture content, $h$ is the pressure head, $\theta_{\text {sat }}$ is the saturated moisture content, $\theta_{\text {res }}($ residual moisture content) $\alpha$ and $\mathrm{n}$ are fitting parameters and $\mathrm{m}=1-1 / \mathrm{n}$.

The parameters of the water release curve were also used to obtain the predictive unsaturated hydraulic conductivity function derived by Van Genuchten (1980): 


$$
K(h)=K_{\text {sat }} \frac{\left\{1-(\propto h)^{m n}\left[1+(\propto h)^{n}\right]^{-m}\right\}^{2}}{\left[1+(\propto h)^{n}\right]^{m l}}
$$

117 In which $K(h)$ is the unsaturated hydraulic conductivity and $K_{\text {sat }}$ is the saturated hydraulic

118 conductivity measured using a falling head permeameter.

119 Following Dexter (2004), Equation 1 was differentiated with respect to the natural

120 logarithm of the pressure head to give an indication of the pore size distribution, maximum

121 pore size and frequency of pores in this maximum pore class:

$\frac{\partial \theta}{\partial \ln (h)}=-m n\left(\theta_{\text {sat }}-\theta_{\text {res }}\right) \alpha^{n} h^{n}\left[1+(\propto h)^{n}\right]^{-m-1}$

The peak of the differentiated function (the inflection point of the release curve),

123 indicates where drainage is maximum and is characterised by its location and slope. The

124 location is given by the pressure $h_{i}$ and occurs at (Dexter, 2004):

$h_{i}=\frac{1}{\propto}\left[\frac{1}{m}\right]^{\frac{1}{n}}$

125 with a corresponding water content, $\theta_{i}$ :

$\theta_{i}=\left(\theta_{\text {sat }}-\theta_{\text {res }}\right)\left[1+\frac{1}{m}\right]^{-m}+\theta_{r e s}$

126 The slope of the curve, S, at this point is the modulus of (Dexter, 2004):

$S=\mid n\left(\theta_{\text {sat }}-\theta_{\text {res })}\left[1+\frac{1}{m}\right]^{-(1+m)} \mid\right.$

127 The water potential $h_{i}$, is representative of the dominant pore size of the soil where the specific water capacity is greatest. Hence, $\mathrm{S}$ at this point can be considered as an overall index of physical and structural quality and it has been correlated to other key soil quality

130 indicators such as bulk density and organic matter content (Dexter, 2004; Dexter and Czyz,

131 2007). Dexter (2004) classed soils with an $\mathrm{S}$ value of $\geq 0.035$ (when $\theta, \mathrm{g}^{\mathrm{g}} \mathrm{g}^{-1}$, is expressed on a

132 gravimetric basis) as being of good physical quality, while most soils studied by Dexter and 133 Czyz (2007) had an S value between 0.015 and 0.060 . 

combination with other physical quality parameters especially for structureless or single grain materials such as composts. Hence, a series of other physical quality parameters (Reynolds et al., 2009) were measured to augment this index: the plant available water capacity (PAWC), defined as the difference between the moisture contents at $50 \mathrm{~cm}$ and at $1.510^{4} \mathrm{~cm}$; the drainable porosity (DP) which is the proportion of air filled pores at field capacity calculated as the difference between the moisture contents at saturation and at $50 \mathrm{~cm}$; and the relative field capacity (RFC) which indicates the ability of the soil to store water and air relative to the soils total pore volume and is calculated as the ratio of moisture content at $50 \mathrm{~cm}$ to that at saturation (Reynolds et al., 2009).

Numerical simulations

146 The water regime of the field profiles, amended with compost at the rates of 250, 500 and $750 \mathrm{t} / \mathrm{ha}$, was simulated using the numerical model Hydrus-1D which uses linear finite

148 element schemes to solve Richards' equation for saturated-unsaturated water flow (Simunek, 149 2008). The size of the simulated $1 \mathrm{D}$ profile was $0.8 \mathrm{~m}$ depth and consisted of two materials with a profile discretisation of 500 nodes. The top $0.1 \mathrm{~m}$ consisted of the compost-amended materials (soil profile descriptions showed this to be the incorporation depth across all rates in the field) and $0.7 \mathrm{~m}$ consisted of the underlying clay cap material. For each layer, the hydraulic parameters (Equations 1 and 2) used in the model were those obtained from the water release and hydraulic conductivity measurements carried out on the undisturbed field cores. In addition to the existing field profiles, alternative scenarios were considered to assess the impact of incorporation depth and indigenous soil type on the hydraulic functioning of such profiles. In the case where sandy loam was used as the indigenous subsoil, the hydraulic parameters used were those of the homogenised samples. In all simulations the upper 
boundary was set as an atmospheric boundary with a maximum surface ponding of $0 \mathrm{~mm}$ allowed before the onset of run-off. This time variable boundary condition consisted of precipitation and daily potential evapotranspiration calculated using the Penman-Monteith equation (Allen, 1998) with meteorological data from a land surface station approximately 6

163 miles from the field site (BADC, 2010). The simulation time was 2 years (2008 and 2009).

164 The lower boundary was set to free drainage (zero-gradient boundary condition). An initial pressure head of $200 \mathrm{~cm}$ was applied to the entire profile. These simulations were primarily used for a qualitative appraisal of the influence of application rate, incorporation depth and indigenous soil type acknowledging that field variability could impact on water regime and that, in the case of the sandy loam subsoil, the homogenised samples used may not be representative of field conditions where structure may develop.

\section{Statistical analysis}

ANOVA were carried out using Statistica 9 (Statsoft inc, 2010) for analysis of measured points of the water release curve, saturated and unsaturated hydraulic conductivity (using modelled values), Van Genuchten parameters and physical quality data. To ensure a balanced factorial design, one analysis excluded the two composts to evaluate the impact of compost on the different soils and one excluded the three unamended soils to analyse the impact of compost type. $\mathrm{P}$ values $>0.05$ were considered not significant.

\section{Results and discussion}

Hydraulic functions

181 Water release characteristics were affected by the addition of compost but also by diesel contamination (Table 1, Figure 1). The diesel-spiked sandy loam (Figure 1c) had smaller

183 water retention at all tensions $(\mathrm{p}<0.01)$ and lower air entry pressure (larger $\alpha, \mathrm{p}<0.02)$ 
compared to the uncontaminated sandy loam, (Figure 1a). Saturated hydraulic conductivity was greater in the diesel-spiked soil $(\mathrm{p}<0.01)$ but unsaturated hydraulic conductivity was significantly less $(\mathrm{p}<0.04)$ for pressure heads ranging from 0 to $2 \times 10^{3} \mathrm{~cm}$ (data not shown).

187 These results agree with those of Hyun et al. (2008), who found reduced unsaturated

188 hydraulic conductivity, less water retention and larger $\alpha$ in a diesel contaminated soil compared to a bioremediated counterpart. The initial diesel concentration (12.5 g/kg in 2006) corresponded to a low residual volumetric diesel content of $1.7 \%$, assuming a diesel density

191 of $0.8 \mathrm{~g} / \mathrm{cm}^{3}$. Furthermore, the total petroleum hydrocarbon concentration measured in 2010 192 had reduced to $83 \mathrm{mg} / \mathrm{kg}$ due to aging. This corresponded to a negligible volumetric content 193 of $0.01 \%$ indicating no significant quantity of free phase diesel and unlikely changes in water content due to interfacial tension effects between free oil and aqueous phases. It is therefore plausible that the reduction in water retention and unsaturated hydraulic conductivity was due to the adsorption of organic compounds onto the soil, leading to a reduction in wettability, as well as their dissolution in water, which resulted in reduced interfacial tension between water

198 and air. These potential changes in wettability were corroborated by Whelan et al. (2010)

199 who measured apparent contact angles as high as $141^{\circ}\left( \pm 10^{\circ}\right)$ on the same soil under dry 200 conditions using the sessile drop method (Bachmann et al., 2000). It is also possible that the dominant pore size of the sandy loam (Figure 2a) increased following diesel addition (Figure 2c), explaining the increase in saturated conductivity. Although not quantified, some aggregation was observed in the diesel-contaminated samples. This could explain the increase

204 in macroporosity and is consistent with the findings of Martinho et al. (2009) who measured a $20 \%$ increase in the proportion of aggregates between 0.05 and $0.5 \mathrm{~mm} 12$ months after the addition of diesel to a loamy soil. They attributed this aggregation to diesel degrading microorganism activity. 

water retention (significant for green compost at $5 \times 10^{3}, 1 \times 10^{4}$ and $1.5 \times 10^{4} \mathrm{~cm}$ pressures, $\mathrm{p}<0.04$, and for meat compost at all pressures below $200 \mathrm{~cm}, \mathrm{p}<0.01) . \alpha$ and $n$ remained unaltered but $\theta_{\text {res }}$ increased significantly (Table2, $\mathrm{p}<0.05$ ). Saturated hydraulic conductivity

212 decreased following the addition of both composts $(\mathrm{p}<0.05)$ but unsaturated hydraulic

213 conductivity only decreased significantly between 30 and $2 \times 10^{3} \mathrm{~cm}$ by the addition of meat compost $(\mathrm{p}<0.04)$. The large value of saturated hydraulic conductivity for diesel-spiked soil, which may be explained by aggregation, was reduced by the addition of compost, in contrast to results from other studies, and suggests that compost mostly resulted in an increase in

217 hydraulic conductivity (Aggelides and Londra, 2000).

218 In contrast, green compost had no impact on water retention and unsaturated hydraulic conductivity of the uncontaminated sandy loam (Figure 1a). Meat compost, however, increased retention at pressures larger than $10^{3} \mathrm{~cm}(\mathrm{p}<0.04)$ and decreased unsaturated hydraulic conductivity at pressures less than $5 \times 10^{3} \mathrm{~cm}(\mathrm{p}<0.04)$. Saturated hydraulic conductivity was increased by green compost $(\mathrm{p}<0.01)$ but decreased with meat compost (Table 2). This increase in retention at higher pressures and decrease in conductivity following meat compost addition, combined with no significant increase in total porosity, suggests an increase in microporosity. The water release characteristics of the two composts (curves not shown) were not significantly different but the meat compost had a smaller saturated hydraulic conductivity and larger organic matter content. Hence, the greater retention at the dry end may be due to the larger specific surface area provided by this additional organic matter (Khaleel et al, 1981). retention at all pressures except 0,30 and $50 \mathrm{~cm}(\mathrm{p}<0.05)$. This was associated with a

232 decrease in $\theta_{\text {res }}(\mathrm{p}<0.04)$ but a increase in $\theta_{\text {sat }}(\mathrm{p}<0.02)$ and therefore total porosity (Table 1$)$. 
233 This indicated a decrease in microporosity and an increase in macroporosity. Meat compost,,

234 on the other hand, increased retention at 0,30 , and $50 \mathrm{~cm}$ pressures $(\mathrm{p}<0.02)$, suggesting an

235 increase in macroporosity. The saturated and unsaturated hydraulic conductivity of the clay

236 loam was increased by the application of both composts (at all pressures with green compost,

$237 \mathrm{p}<0.01$, and at 0 and between 30 and $10^{4} \mathrm{~cm}$ with meat compost, $\left.\mathrm{p}<0.05\right)$. The reduction in

water retention caused by green compost contrasted with other studies, which found compost to increase retention for a series of clay, loam and clay loam soils (Aggelides and Londra,

studies and agrees with Khaleel et al. (1981) who suggested the addition of organic matter to fine textured soils primarily increases retention around field capacity. retention at pressures less than $500 \mathrm{~cm}$ for all of the three application rates $(\mathrm{p}<0.05)$.

Retention increased with increasing application rate for pressures up to $100 \mathrm{~cm}$, however, this saturated hydraulic conductivity also increased with compost application rate $(\mathrm{p}<0.03)$. This increase in conductivity and retention at the wet end of the release curve associated with an increase in $\theta_{\text {sat }}$ (Table 1 ) is explained by an increase in macroporosity and in dominant pore size (Figure 2d). However, the small difference between 500 and $750 \mathrm{t} /$ ha is consistent with the results of Aggelides and Londra (2000), who found application rate had no significant effect on clay.

Dominant pore size and physical quality parameters

The diesel-spiked sandy loam had a larger dominant pore size (Figure 2c), represented by a lower $h_{i}$ (Table 2), compared to the uncontaminated sandy loam $(\mathrm{p}<0.01)$. This supports the results of Hyun et al. (2008) who found a larger dominant pore size in a diesel-spiked soil 
compared to its bioremediated counterpart. However, this shift in pore size may not be as

259

260

261

262

263

264

265

266

267

268

269

270

271

272

273

274

275

276

277

279

280

281

pronounced as suggested in Figure 2c because it may be partly reflective of changes in

interfacial properties caused by diesel rather than changes in pore size distribution alone. This

artefact results in a large $S$ index despite other parameters being indicative of poor quality

(Table 2). Diesel contamination results in a larger DP ( $<<0.01)$, and smaller PAWC $(\mathrm{p}<0.05)$, and RFC $(\mathrm{p}<0.05)$.

The addition of both composts to the diesel-spiked soil did not significantly alter the dominant pore size, S, PAWC, DP or RFC (Table 2). DP, RFC and PAWC were less than optimum, suggesting little improvement in water availability despite the large compost application rate. The addition of meat compost to the sandy loam $(\mathrm{p}<0.04)$ and green compost to the clay loam $(\mathrm{p}<0.01)$ increased the dominant pore size (Figures $2 \mathrm{a}$ and $2 \mathrm{~b}$, Table 2 ). The $S$ index increased in the clay loam $(\mathrm{p}<0.01)$ but not in the sandy loam. For both soils, DP increased significantly while PAWC and RFC decreased. However, whilst these parameters were within optimum ranges for the sandy loam, clay loam showed poor physical quality and an aeration deficit.

The dominant pore size of the field clay subsoil increased significantly following compost addition (Figure 2d, Table 2) but the difference between application rates was not significant. The $S$ index was above optimum for all three rates but greatest for $500 \mathrm{t} / \mathrm{ha}$. DP remained below optimum whereas PAWC only exceeded the optimum value in the $500 \mathrm{t} / \mathrm{ha}$ treatment. RFC, remained large and outside the optimum range. These results indicate that the soils suffer from poor aeration and an excess of water but that this water is not always available for the plant. Hence, the improvement in the hydraulic properties of the structureless clay subsoil remains limited despite the large compost application rate used.

\section{Numerical simulation of water flow in amended soil profiles}


283 A typical field profile description is shown in Figure 3. All profiles showed similar features.

284 For all application rates, the compost layer, which had a granular texture, formed a distinctive

285

286

287

289

290

291

292

293

294

295

296

297

298

299

300

301

302

303

304

305 boundary with the underlying dark grey clay that was massive, structureless and contained some brick like debris. The compost had been incorporated to a depth of approximately 10 $\mathrm{cm}$ in all application rates and plant roots were unable to penetrate the clay subsoil.

The capacity of the profiles to retain water was examined by calculating the overall water storage for both the compost layer and the clay subsoil. The water storage is analysed in relation to the plant available water capacity, where storage corresponding to moisture contents lower than $50 \%$ available water or higher than field capacity are considered likely to induce plant stress. For 250 t/ha, the compost layer had a moisture content of less than $50 \%$ available water for 322 days out of 731 days, suggesting this profile was very dry (Figure 4a). The longest period in which the moisture content was continuously below $50 \%$ available water was 32 days (Table 3). In contrast, for $750 \mathrm{t} / \mathrm{ha}$, the compost layer had a moisture content above field capacity for 293 days, with periods of up to 32 days continuously above field capacity (Figure 4c). For 500 t/ha, the compost layer had only 126 days in which the moisture content was above field capacity and 219 days in which it was less than $50 \%$ available water (Figure 4b). The clay subsoil had a moisture content within optimum ranges for most of the simulation period (Figure 4d). However, since roots were limited to the compost layer, its moisture content will have more bearing on plant growth than that of the clay subsoil. The excessive moisture content in the soil amended at $750 \mathrm{t} / \mathrm{ha}$ was reflected in the yields of the field crops (Lord and Green, 2011) with only the reed canary grass, which is a wetland species, producing a commercial yield.

To illustrate the influence of the clay subsoil on the hydraulic functioning of the profiles, the water balance was examined in detail for Day 251. This day saw the largest amount of rainfall $(53.2 \mathrm{~mm})$ recorded, which resulted in saturation of the compost layer for 
all three rates. However, the flow rate became restricted to the saturated hydraulic conductivity of the clay subsoil $(40 \mathrm{~mm} / \mathrm{d})$ and positive water pressures of up to $9 \mathrm{~cm}$, building up at the interface between the compost layers and the clay, indicated that the clay was acting as a permeability barrier. Over the 2-year period, precipitation rates exceeding the

312 hydraulic conductivity of the clay resulted in runoff when the profiles became saturated. The

313 lower volume of runoff generated by the $750 \mathrm{t} /$ ha treatment (Table 3 ) is explained by the

314 higher porosity and higher retention capacity of the compost layer, which result in higher mean water storage, but also its greater hydraulic conductivity which result in a larger cumulative drainage volume (Table 3).

Alternative profile designs were considered to examine how incorporation depth or the type of subsoil would influence the moisture regime. Simulation of the clay cap amended with $750 \mathrm{t} / \mathrm{ha}$ of compost incorporated to a depth of $30 \mathrm{~cm}$ instead of $10 \mathrm{~cm}\left(0.25 \mathrm{t} / \mathrm{m}^{3}\right.$ as opposed to $0.75 \mathrm{t} / \mathrm{m}^{3}$ ), indicated a large reduction, from 293 to 34 , in the number of days in which the compost water storage was above field capacity but an increase, from 0 to 195 , in the number of days in which it was below 50\% available water (Figure 5). As such deeper incorporation seems to increase water availability in the compost layer. This will also increase the volume of soil available for root growth and therefore access to this available water. Simulations of water flow in a more permeable sandy loam amended with $750 \mathrm{t} / \mathrm{ha}$ of compost with $30 \mathrm{~cm}$ incorporation resulted in a dryer profile (Figure 5). Compared to the amended clay cap profile, the compost layer in the sandy loam profile had a lower number of days in which moisture content was above field capacity and a larger number of days in which both the amended layer and the subsoil had a moisture content below $50 \%$ available water (Figure 5) indicating that the soil profile may be too dry for successful plant growth. 


\section{Conclusions}

334 The improvement in water retention and physical quality brought about by large applications

335 of compost varied with soil type and initial soil quality but were also affected by compost

336 type and diesel contamination. Compost addition to a sandy loam had little influence on

337 water retention, pore size distribution and soil physical quality indicators. Diesel contamination in the same sandy loam reduced retention. Compost did not fully restore retention and the physical quality parameters showed little improvement in water availability.

340 Despite an increase in macroporosity and hydraulic conductivity, the compost amended clay

341 loam had poor physical quality and aeration. Undisturbed field samples from the clay cap

342 amended with 250,500 or 750 t/ha had water retention above field capacity and hydraulic

343 conductivity and physical quality that increased with increasing compost application rate.

344 Differences between the 500 and 750 t/ha rates were small. Thus there appears to be little

345 further benefit from applying such large rates of compost. This was also corroborated by the

346 numerical simulations which indicated shallow incorporation of large amounts of compost

347 resulted in distinct layering of the soil profile and long periods during which the profile had

348 inadequate moisture for satisfactory plant growth. Soil amended with $500 \mathrm{t} / \mathrm{ha}$ had the most

349 favourable water regime with a greater number of days in which aeration and water

350 availability were optimum. Deeper incorporation improved the moisture status of the soil

351 profile. Conversely, simulations with a more permeable subsoil showed that the depth to

352 which the profile dried below optimum moisture contents increased, suggesting that deep

353 incorporation into coarser soils may not always be appropriate.

354

355

356 
358 Acknowledgements

359 This research was supported by Cranfield University and the Waste and Resources Action

360 Programme (WRAP). The field site was established using funding from WRAP and the Life

361 III Environment Programme.

362

363 


\section{References}

365

366

367

368

369

370

371

372

374

375

376

377

378

379

380

381

382

Aggelides, S.M. \& Londra, P.A. 2000. Effects of compost produced from town wastes and sewage sludge on the physical properties of a loamy and a clay soil. Bioresource Technology, 71, 253-9.

Allen, R.G. 1998. Crop Evapotranspiration Guidelines For Computing Crop Water Requirements: Guidelines for Computing Crop Water Requirements, Fao Irrigation and Drainage Paper 56

Antizar-Ladislao, B., Lopez-Real, J. \& Beck, A.J. 2005. Laboratory studies of the remediation of polycyclic aromatic hydrocarbon contaminated soil by in-vessel composting. Waste Management, 25, 281-289.

Bachmann, J., Ellies, A. \& Hartge, K.H. 2000. Development and application of a new sessile drop contact angle method to assess soil water repellency. Journal of Hydrology, 231-232, $66-75$.

British atmospheric data centre (BADC). 2010. Metoffice MIDAS land surface observation data. http://badc.nerc.ac.uk

Charles, M.B., Ryan, R., Ryan, N. \& Oloruntoba, R. 2007. Public policy and biofuels: The way forward?. Energy Policy, 35, 5737-5746.

Dexter, A.R. 2004. Soil physical quality: Part I. Theory, effects of soil texture, density, and organic matter, and effects on root growth. Geoderma, 120, 201-214.

Dexter, A.R. \& Czyz, E.A. 2007. Applications of s-theory in the study of soil physical degradation and its consequences. Land Degradation and Development, 18, 369-381.

Gandolfi, I., Sicolo, M., Franzetti, A., Fontanarosa, E., Santagostino, A. \& Bestetti, G. 2010. Influence of compost amendment on microbial community and ecotoxicity of hydrocarboncontaminated soils. Bioresource technology , 101, 568-575. 
Hyun, S., Ahn, M., Zimmerman, A.R., Kim, M. \& Kim, J. 2008. Implication of hydraulic properties of bioremediated diesel-contaminated soil. Chemosphere , 71, 1646-1653.

391 Kechavarzi, C., Soga, K., Illangasekare, T. 2005. Two-dimensional laboratory simulation of LNAPL infiltration and redistribution in the vadose zone. Journal of Contaminant hydrology, 76, 211-233.

Kechavarzi, C., Dawson, Q., Leeds-Harrison, P.B. 2010. Physical properties of low-lying agricultural peat soils in England. Geoderma, 154, 196-202.

Khaleel, R., Reddy, K.R. \& Overcash, M.R. 1981. Changes in soil physical properties due to organic waste applications: A review. J Environ Qual , 10, 133-144.

Lord, R. and Green, R., (2011). Performance and characteristics of perennial rhizomatous grasses grown on non-agricultural land - a sustainable fuel source without food displacement. In Proceedings of the bioten conference on biomass, bioenergy and biofuels 2010 (A.V. Bridgewater ed.), CPL Press, 78-93.

Reynolds, W.D., Drury, C.F., Tan, C.S., Fox, C.A. \& Yang, X.M. 2009. Use of indicators and pore volume-function characteristics to quantify soil physical quality. Geoderma, 152, 252-263.

Riddell-Black, D., 2002. Bioremediation and Economic Renewal of Industrially Degraded Land by Biomass Fuel Crops (BIORENEW). European Commission Environment Research Programme. Summary Report. ISBN 1857058836.

Said-Pullicino, D., Massaccesi, L., Dixon, L., Bol, R. \& Gigliotti, G. 2010. Organic matter dynamics in a compost-amended anthropogenic landfill capping-soil. European Journal of Soil Science, 61, 35-47.

Semple, K.T., Reid, B.J. \& Fermor, T.R. 2001. Impact of composting strategies on the treatment of soils contaminated with organic pollutants. Environmental Pollution, 112, 269283. 
414 Šimůnek, J., Šejna, M., Saito, H., Sakai M., \& van Genuchten, M. T. 2008. The HYDRUS-

415 1D Software Package for Simulating the One-Dimensional Movement of Water, Heat, and

416 Multiple Solutes in Variably-Saturated Media. Department of environmental sciences,

417 university of California, Riverside.

418 Statsoft. 2010. Statistica, 9.

419 van Genuchten, M.T. 1980. A closed form equation for predicting the hydraulic conductivity

420 of unsaturated soils. Soil Science Society of America Journal, 44, 892-8.

421 van Genuchten, M.T., Leij, F.J. \& Yates, S.R. 1991. The RETC Code for Quantifying the

422 Hydraulic Functions of Unsaturated Soils.

423 Wanas, S.A. \& Omran, W.M. 2006. Advantages of applying various compost types to

424 different layers of sandy soils: Hydro-physical properties. Journal of Applied sciences

425 research, $2,1298-1303$.

426 Whelan A., Kechavarzi C., Sakrabani R., Coulon F., The influence of compost addition on

427 the hydraulic properties of brownfield soils, proceedings of CONSOIL 2010, $21^{\text {st }}-24^{\text {th }}$

428 September 2010, Salzburg, Austria, ISBN: 978-3-00-032099-6.

429

430 

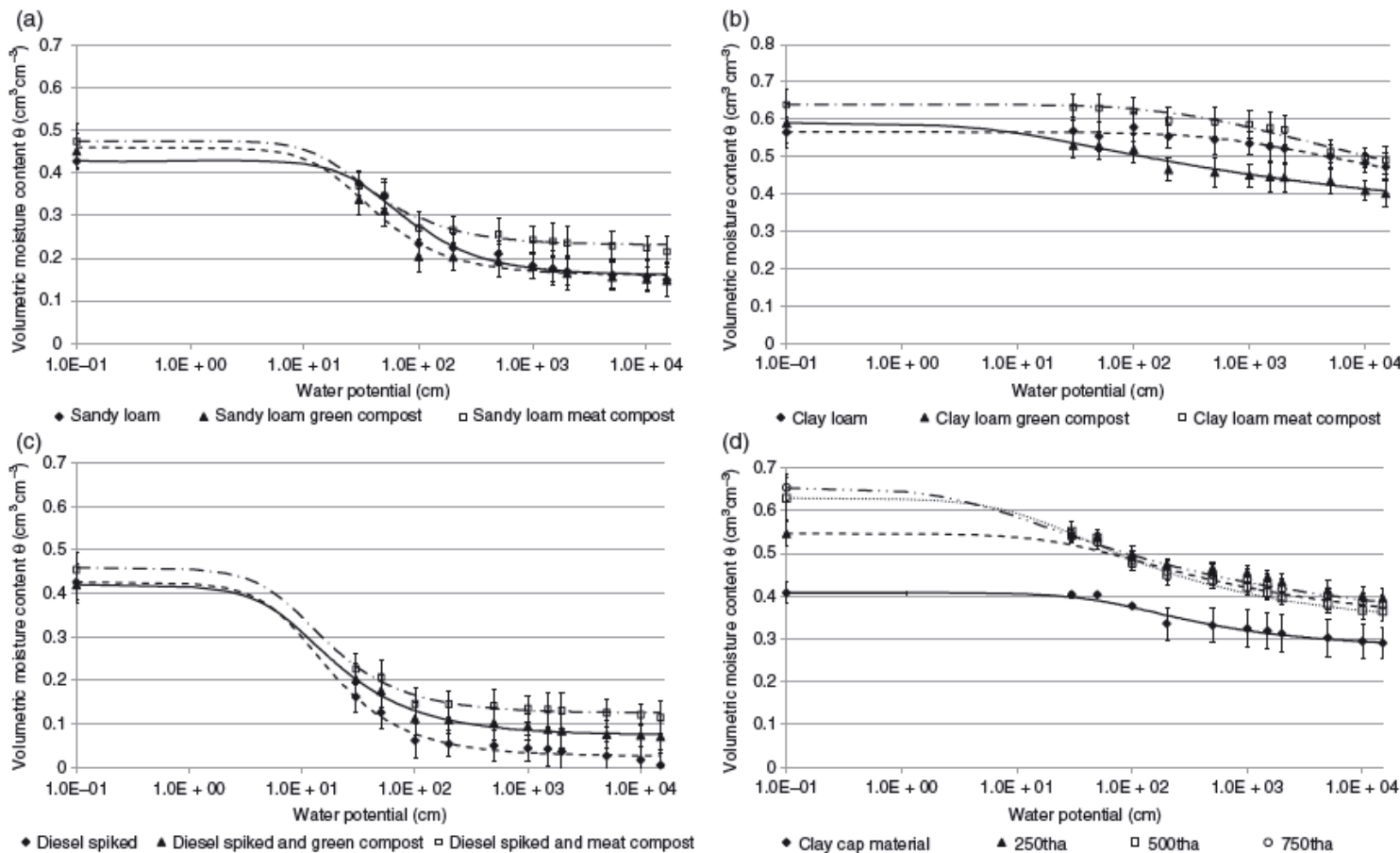

433 Fig. 1. Water release curves of unamended and compost amended soils fitted with the Van 434 Genuchten equation: (a) sandy loam; (b) clay loam; (c) diesel spiked sandy loam; (d) field 435 clay cap.

(a)
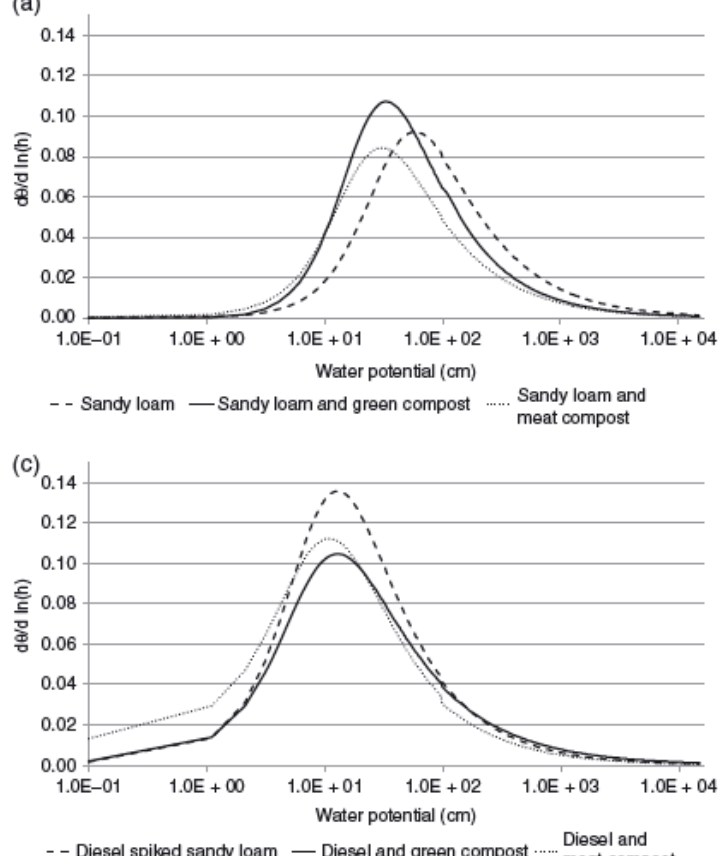
(c) diesel spiked sandy loam; (d) field clay cap. (b)

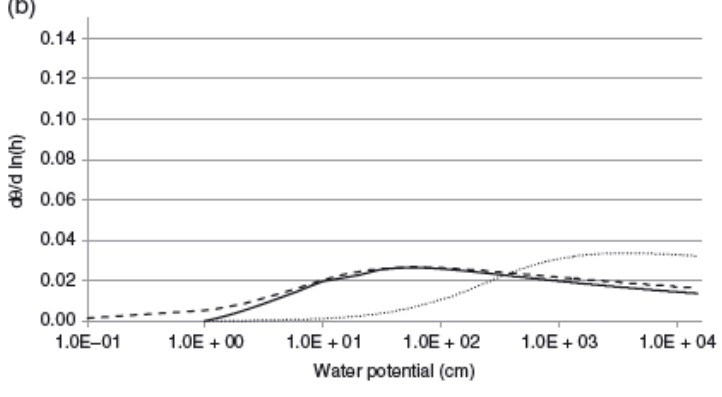

- - Clay loam - Clay loam and green compost ...... Clay loam and meat compost

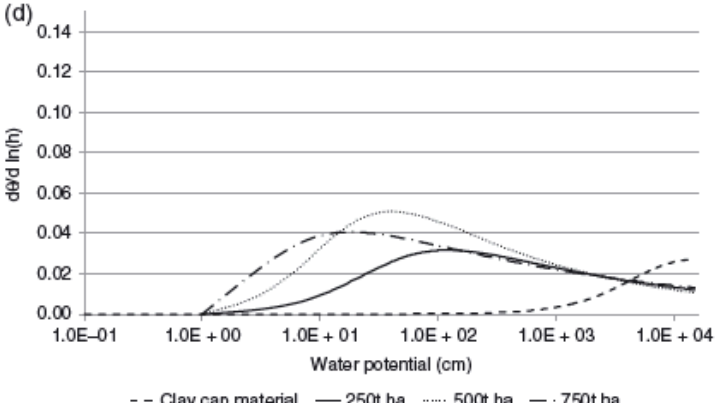

Fig. 2. Pore size distribution of unamended and compost amended soils represented by the plot of the slope of the release curves against water potential: (a) sandy loam; (b) clay loam; 


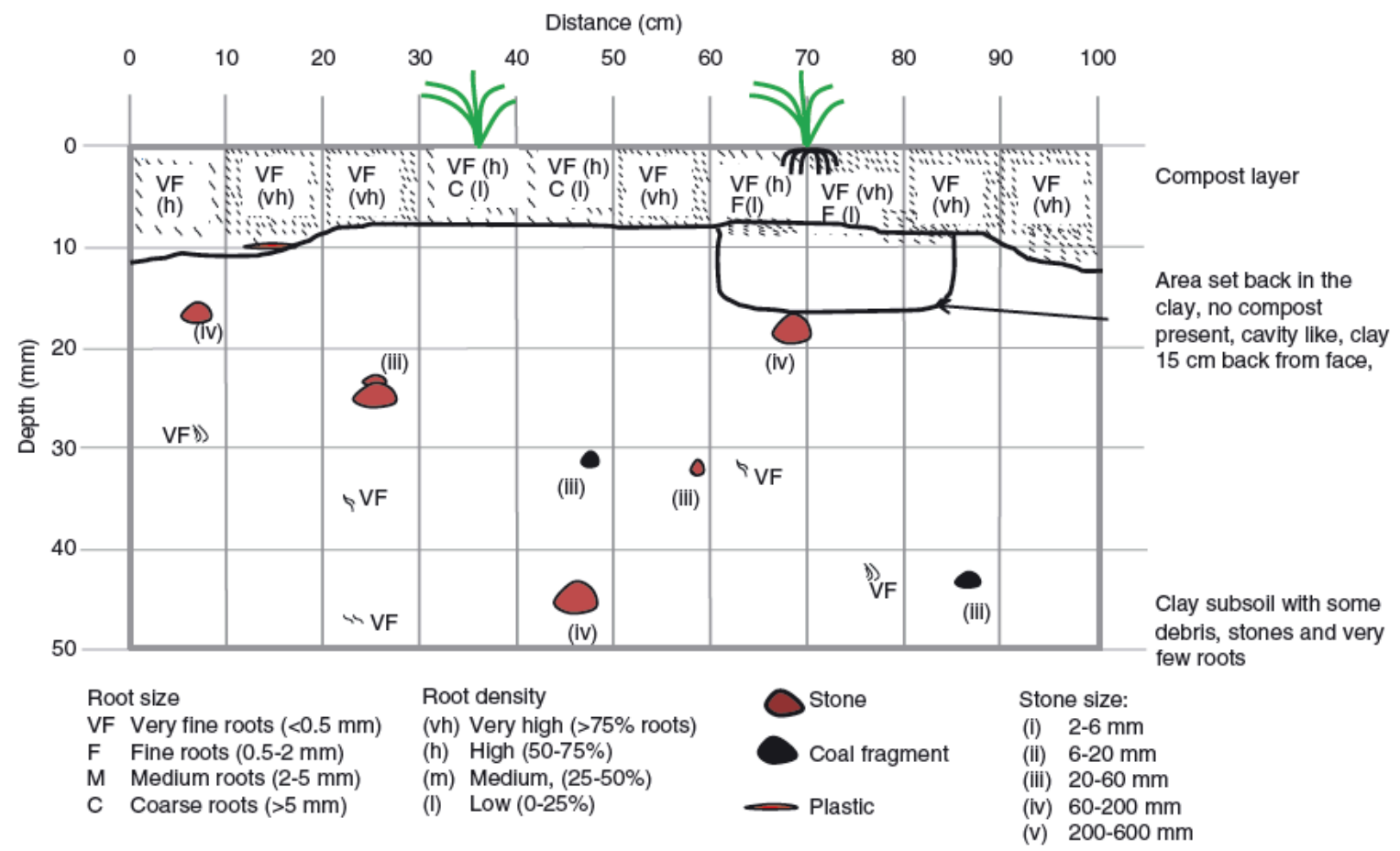

442 Fig. 3. Typical field profile description: clay cap material amended with 750 t/ha of compost 443 to a depth of $10 \mathrm{~cm}$ and planted with reed canary grass.
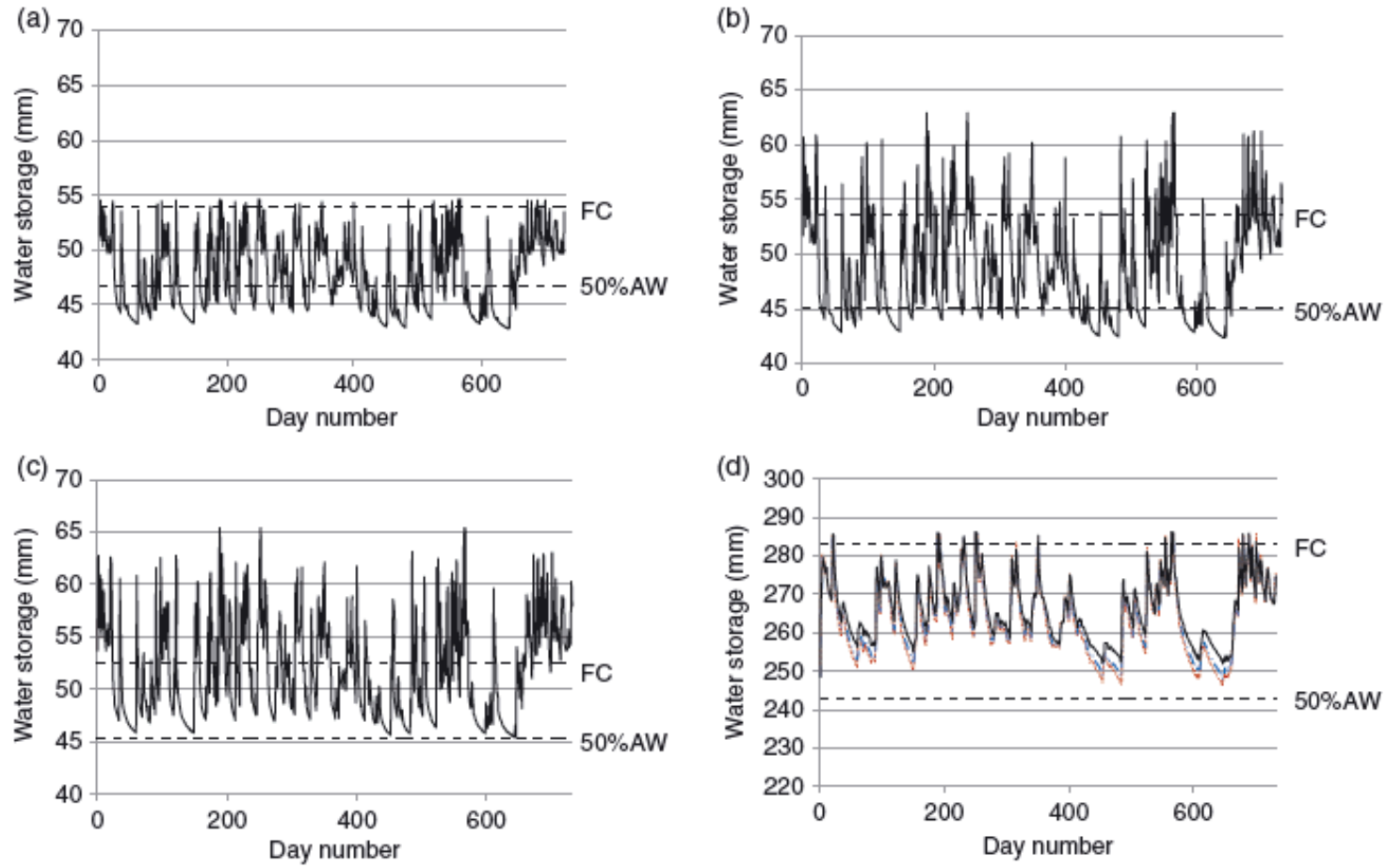

..... 250t/ha.- .500 tha -750 tha

445 Fig. 4. Mean water storage in the $10 \mathrm{~cm}$ compost layer of the field profiles amended at (a) $446250 \mathrm{t} / \mathrm{ha}$, (b) $500 \mathrm{t} / \mathrm{ha}$ and (c) $750 \mathrm{t} / \mathrm{ha}$. (d) Mean water storage in the $70 \mathrm{~cm}$ clay cap subsoil 447 layer of the field profiles amended at 250, 500 and $750 \mathrm{t} / \mathrm{ha}$. 


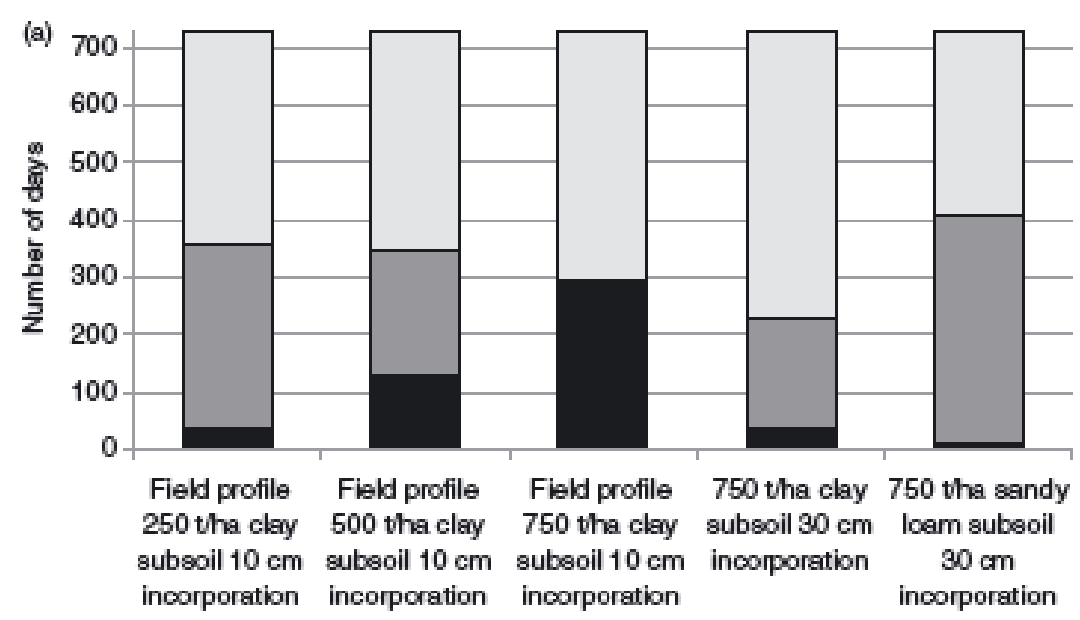

Simulation description

Deys with optimum

$\checkmark$ moisture content

Days below $50 \%$

$\square$ available water

Days above field capacity

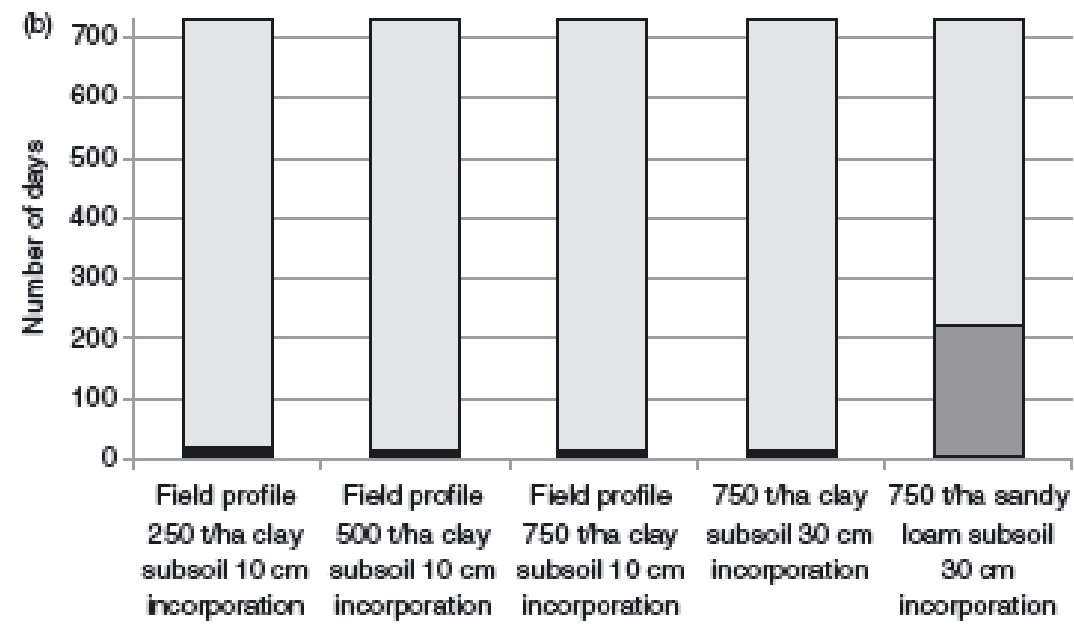

Simulation description

Days with optimum
moisture content $\quad \begin{aligned} & \text { Days below } 50 \% \\ & \text { gvailable water }\end{aligned}$

451 Fig. 5. Number of days with mean moisture content within optimum range, below 50\% available water or above field capacity for (a) the compost layer and (b) the subsoil. 
455 Table 1van Genuchten parameters for water-release curves and moisture content at

456 permanent wilting point (PWP), field capacity (FC) and when $50 \%$ of the available water

457 (AW) is depleted

\begin{tabular}{|c|c|c|c|c|c|c|c|c|}
\hline Sample & $\begin{array}{c}\theta_{\text {sat }} \\
\left(\mathrm{cm}^{3} / \mathrm{cm}^{3}\right)\end{array}$ & $\begin{array}{c}\theta_{\text {res }} \\
\left(\mathrm{cm}^{3} / \mathrm{cm}^{3}\right)\end{array}$ & $n$ & $\begin{array}{c}\alpha \\
(\text { per m) }\end{array}$ & $1 / \alpha(\mathrm{m})$ & $\begin{array}{c}\theta \text { PWP } \\
\left(\mathrm{cm}^{3} / \mathrm{cm}^{3}\right)\end{array}$ & $\begin{array}{c}\theta \mathrm{FC} \\
\left(\mathrm{cm}^{3} / \mathrm{cm}^{3}\right)\end{array}$ & $\begin{array}{l}50 \% \text { AW } \\
\left(\mathrm{cm}^{3} / \mathrm{cm}^{3}\right)\end{array}$ \\
\hline Sandy loam & 0.429 & 0.160 & 1.852 & 2.586 & 0.387 & 0.151 & 0.348 & 0.249 \\
\hline $\begin{array}{l}\text { Sandy loam and } \\
\text { green compost }\end{array}$ & 0.460 & 0.161 & 1.905 & 4.514 & 0.222 & 0.149 & 0.313 & 0.231 \\
\hline $\begin{array}{l}\text { Sandy loam and } \\
\text { meat compost }\end{array}$ & 0.476 & 0.232 & 1.859 & 4.864 & 0.206 & 0.217 & 0.348 & 0.283 \\
\hline Diesel-spiked sandy loam & 0.427 & 0.026 & 1.839 & 11.540 & 0.087 & 0.006 & 0.127 & 0.066 \\
\hline $\begin{array}{l}\text { Diesel-spiked and } \\
\text { green compost }\end{array}$ & 0.420 & 0.074 & 1.714 & 12.554 & 0.08 & 0.071 & 0.176 & 0.123 \\
\hline $\begin{array}{l}\text { Diesel-spiked and } \\
\text { meat compost }\end{array}$ & 0.460 & 0.125 & 1.826 & 12.502 & 0.08 & 0.115 & 0.208 & 0.161 \\
\hline Green compost & 0.563 & 0.264 & 1.748 & 11.653 & 0.086 & 0.256 & 0.363 & 0.310 \\
\hline Meat compost & 0.550 & 0.297 & 1.993 & 8.935 & 0.112 & 0.290 & 0.367 & 0.329 \\
\hline Clay loam & 0.566 & 0.223 & 1.108 & 0.136 & 7.353 & 0.473 & 0.564 & 0.518 \\
\hline $\begin{array}{l}\text { Clay loam and } \\
\text { green compost }\end{array}$ & 0.590 & 0.310 & 1.139 & 12.925 & 0.077 & 0.402 & 0.523 & 0.462 \\
\hline Clay loam and meat compost & 0.640 & 0.001 & 1.067 & 0.369 & 2.711 & 0.491 & 0.634 & 0.562 \\
\hline Field samples $250 \mathrm{t} / \mathrm{ha}$ & 0.546 & 0.326 & 1.246 & 3.110 & 0.322 & 0.396 & 0.539 & 0.467 \\
\hline Field samples $500 \mathrm{t} / \mathrm{ha}$ & 0.629 & 0.328 & 1.308 & 7.616 & 0.131 & 0.366 & 0.536 & 0.451 \\
\hline Field samples $750 \mathrm{t} / \mathrm{ha}$ & 0.654 & 0.319 & 1.195 & 25.858 & 0.039 & 0.379 & 0.526 & 0.453 \\
\hline Field clay cap material & 0.408 & 0.279 & 1.421 & 1.520 & 0.658 & 0.291 & 0.404 & 0.347 \\
\hline
\end{tabular}

459

460 Table 2 Physical quality parameters of all soils with optimum suggested values

\begin{tabular}{|c|c|c|c|c|c|c|c|}
\hline Sample & $\begin{array}{l}\text { Hydraulic } \\
\text { conductivity } \\
(\mathrm{m} / \text { day })\end{array}$ & $\begin{array}{l}\text { Drainable } \\
\text { porosity } \\
\left(\mathrm{cm}^{3} / \mathrm{cm}^{3}\right)\end{array}$ & $\begin{array}{c}\text { Plant available } \\
\text { water } \\
\left(\mathrm{cm}^{3} / \mathrm{cm}^{3}\right)\end{array}$ & $\begin{array}{l}\text { Relative } \\
\text { field } \\
\text { capacity }\end{array}$ & $\begin{array}{c}\text { Pressure at } \\
\text { inflection point } \\
h_{i}(\mathrm{~cm})\end{array}$ & $\begin{array}{l}\text { Water content at } \\
\text { inflection point } \theta_{i} \\
\left(\mathrm{~cm}^{3} / \mathrm{cm}^{3}\right)\end{array}$ & $\begin{array}{c}\text { Slope at } \\
\text { inflection } \\
\text { point S }\end{array}$ \\
\hline Sandy loam & $0.44( \pm 0.06)$ & 0.081 & 0.197 & 0.811 & 58 & 0.21 & 0.10 \\
\hline $\begin{array}{l}\text { Sandy loam and } \\
\text { green compost }\end{array}$ & $1.02( \pm 0.46)$ & 0.147 & 0.163 & 0.680 & 33 & 0.25 & 0.08 \\
\hline $\begin{array}{l}\text { Sandy loam and } \\
\text { meat compost }\end{array}$ & $0.17( \pm 0.06)$ & 0.127 & 0.131 & 0.732 & 31 & 0.19 & 0.09 \\
\hline $\begin{array}{l}\text { Diesel-spiked } \\
\text { sandy loam }\end{array}$ & $4.77( \pm 1.86)$ & 0.300 & 0.121 & 0.297 & 13 & 0.31 & 0.12 \\
\hline $\begin{array}{l}\text { Diesel-spiked and } \\
\text { green compost }\end{array}$ & $0.89( \pm 0.20)$ & 0.244 & 0.105 & 0.419 & 13 & 0.24 & 0.12 \\
\hline $\begin{array}{l}\text { Diesel-spiked and } \\
\text { meat compost }\end{array}$ & $0.40( \pm 0.11)$ & 0.252 & 0.093 & 0.452 & 12 & 0.25 & 0.14 \\
\hline Green compost & $22.38( \pm 6.54)$ & 0.199 & 0.108 & 0.646 & 14 & 0.21 & 0.09 \\
\hline Meat compost & $13.32( \pm 4.00)$ & 0.183 & 0.077 & 0.667 & 15 & 0.22 & 0.10 \\
\hline Clay loam & $0.08( \pm 0.12)$ & 0.001 & 0.091 & 0.997 & 6050 & 0.49 & 0.03 \\
\hline $\begin{array}{l}\text { Clay loam and } \\
\text { green compost }\end{array}$ & $0.39( \pm 0.09)$ & 0.085 & 0.121 & 0.887 & 60 & 0.52 & 0.04 \\
\hline $\begin{array}{l}\text { Clay loam and } \\
\text { meat compost }\end{array}$ & $0.15( \pm 0.05)$ & 0.001 & 0.143 & 0.991 & 3650 & 0.54 & 0.04 \\
\hline Field samples $250 \mathrm{t} / \mathrm{ha}$ & $0.07( \pm 0.01)$ & 0.009 & 0.143 & 0.986 & 118 & 0.48 & 0.05 \\
\hline Field samples $500 \mathrm{t} / \mathrm{ha}$ & $0.47( \pm 0.76)$ & 0.035 & 0.170 & 0.853 & 40 & 0.53 & 0.12 \\
\hline Field samples $750 \mathrm{t} / \mathrm{ha}$ & $1.22( \pm 1.39)$ & 0.069 & 0.147 & 0.804 & 18 & 0.56 & 0.09 \\
\hline Field clay cap material & $0.04( \pm 0.01)$ & 0.003 & 0.113 & 0.989 & 155 & 0.36 & 0.04 \\
\hline $\begin{array}{l}\text { Optimum suggested } \\
\text { value (Reynolds } \\
\text { et al., 2009) }\end{array}$ & & $\geq 0.14$ & $\geq 0.15$ & $0.6-0.7$ & & & $>0.035$ \\
\hline
\end{tabular}


462 Tabe 3 Drainage, run-off, mean water storage and duration of longest periods above field

463 capacity or below 50\% available water in compost layer

\begin{tabular}{|c|c|c|c|c|c|}
\hline & $\begin{array}{l}\text { Cumulative drainage } \\
\text { from bottom of profile } \\
(\mathrm{mm})\end{array}$ & $\begin{array}{c}\text { Run- } \\
\text { off } \\
(\mathrm{mm})\end{array}$ & $\begin{array}{l}\text { Mean water } \\
\text { storage } \\
(\mathrm{mm})\end{array}$ & $\begin{array}{l}\text { Longest period above Field } \\
\text { capacity in compost layer } \\
\text { (days) }\end{array}$ & $\begin{array}{c}\text { Longest period below } 50 \% \\
\text { available water in compost } \\
\text { layer (days) }\end{array}$ \\
\hline $\begin{array}{l}\text { Field profile } 250 \mathrm{t} / \mathrm{ha} \text { - clay } \\
\text { subsoil }-10 \mathrm{~cm} \\
\text { incorporation }\end{array}$ & 1184 & 24.5 & 47.8 & 2 & 32 \\
\hline $\begin{array}{l}\text { Field profile } 500 \mathrm{t} / \mathrm{ha} \text { - clay } \\
\text { subsoil }-10 \mathrm{~cm} \\
\text { incorporation }\end{array}$ & 1190 & 17.7 & 48.8 & 5 & 29 \\
\hline $\begin{array}{l}\text { Field profile } 750 \mathrm{t} / \mathrm{ha} \text { - clay } \\
\text { subsoil }-10 \mathrm{~cm} \\
\text { incorporation }\end{array}$ & 1287 & 15.8 & 51.7 & 33 & 0 \\
\hline $\begin{array}{l}750 \mathrm{t} / \mathrm{ha} \text { - clay loam subsoil } \\
-30 \mathrm{~cm} \text { incorporation }\end{array}$ & 1160 & 23.3 & 146.7 & 2 & 28 \\
\hline $\begin{array}{l}750 \mathrm{t} / \mathrm{ha} \text { - sandy loam - } \\
30 \mathrm{~cm} \text { incorporation }\end{array}$ & 1210 & 0 & 70.2 & 2 & 46 \\
\hline
\end{tabular}

